\title{
Penentuan Komposisi Hidroksiapatit-Alginat-Zinc terhadap Kuat Tekan Bone Scaffold dengan Metode Taguchi
}

\author{
Febbyola Raflyani ${ }^{1 *}$, Tri Wibawa ${ }^{2}$, Sadi $^{3}$ \\ 1,2,3 Jurusan Teknik Industri, Universitas Pembangunan Nasional "Veteran” Yogyakarta, Yogyakarta, Indonesia \\ ( ${ }^{*} 122170038 @$ student.upnyk.ac.id)
}

\begin{abstract}
Abstrak - Indonesia merupakan negara berkembang dengan tingkat mobilitas masyarakat yang berkendara cukup tinggi. Seiring dengan bertambahnya kebutuhan transportasi menyebabkan tingkat kecelakaan lalu lintas juga semakin meningkat. Permasalahan ini menyebabkan luka hingga patah tulang bagi para korban. Untuk menangani masalah tersebut, perlu diadakannya pencangkokan tulang (bone graft). Pada penelitian ini akan dirancang material tulang pengganti manusia yang berasal dari campuran Hidroksiapatit dengan Alginat dan Zinc. Hasil pencampuran material akan dilakukan pengujian kuat tekan dan data akan diolah dengan menggunakan metode Taguchi. Target uji tekan yaitu 7,5-41 MPa dengan karakteristik kualitas larger-the-better. Sedangkan desain eksperimen yang digunakan yaitu $\mathrm{L}_{4} 2^{3}$. Hasil dari perhitungan ANOVA menunjukkan bahwa faktor komposisi HA, komposisi Alginat, dan rasio HA:Aquades memiliki hasil yang signifikan. Terhadap kuat tekan scaffold. Namun, hasil perhitungan ANOVA terhadap nilai SNR menunjukkan bahwa ketiga faktor tersebut tidak memiliki kontribusi pada pengurangan variansi suatu karakteristik kualitas. Komposisi material scaffold yang paling optimal yaitu komposisi HA 88\%wt, komposisi Alginat 8\%wt, dan rasio HA:Aquades 1:1,5. Hasil nilai kuat tekan pada komposisi tersebut sebesar 8,197 $\pm 0,259$ MPa dimana nilai ini sesuai dengan nilai kuat tekan untuk tulang cancellous.
\end{abstract}

Kata kunci: bone scaffold; desain eksperimen; metode Taguchi; uji kuat tekan

\section{PENDAHULUAN}

Indonesia merupakan negara berkembang dengan tingkat mobilitas masyarakat yang berkendara cukup tinggi. Seiring dengan bertambahnya jumlah penduduk tiap tahunnya menyebabkan kebutuhan transportasi pun semakin meningkat. Menurut Badan Pusat Statistik (BPS) pada periode 2018, jumlah kendaraan di Indonesia sebesar 146.858.749 unit termasuk sepeda motor, mobil barang, mobil bis, maupun mobil penumpang. Secara tidak langsung, hal ini menyebabkan tumbuhnya permasalahan transportasi terutama pada resiko kecelakaan. Permasalahan yang berkaitan dengan kecelakaan lalu lintas adalah hal yang sering terjadi. Selama kurun waktu 2014-2018, jumlah kecelakaan lalu lintas mengalami kenaikan dengan rata-rata 3,3\% per tahun. Permasalahan tersebut dapat menyebabkan luka parah hingga mengalami patah tulang serta menelan korban jiwa. Berdasarkan data dari Departemen Kesehatan RI tahun 2013 didapatkan kurang lebih delapan juta orang yang mengalami kelainan fraktur.

Tulang memiliki peranan penting bagi tubuh manusia sebagai alat gerak pasif. Selain itu, tulang juga merupakan pelindung organ dan pengungkit bagi otot. Dengan banyaknya operasi tulang yang harus dilakukan pada pasien fraktur, menyebabkan permintaan akan material pengganti tulang (bone substitute) semakin tinggi. Untuk menangani masalah tersebut, perlu diadakannya pencangkokan tulang (bone graft) untuk mengisi bagian tulang yang kosong dan beregenerasi kembali sesuai dengan fungsi tulang (Ferdiansyah, Rushadi, Rantam, \& Aulani'am, 2011). Tulang merupakan bagian penting yang ada pada tubuh manusia. Tulang memiliki fungsi beragam, diantaranya pelindung organ tubuh seperti jantung dan paru-paru, tempat pembentukan sel darah merah, tulang juga membantu memunculkan gerakan pada tubuh manusia, kerangka yang menopang tubuh manusia, dan pengungkit bagi otot agar tubuh dapat melakukan suatu gerakan dengan maksimal (Triono \& Murinto, 2015). Sehingga, dirancang graft sintetis yang merupakan jenis pengganti tulang yang biokompatibel bagi tubuh manusia. Bahan utama yang digunakan dalam pembuatan scaffold yaitu pencampuran dari Hidroksiapatit dengan Alginat dan Zinc. Hidroksiapatit memiliki kelemahan, yaitu bersifat rapuh, tidak bersifat osteoinduktif, sifat mekanik rendah, dan ketidakstabilan struktur ketika tercampur dengan tubuh manusia (Shojai et al, 2013). Untuk meningkatkan proses osteosis, maka material yang ditambahkan pada penelitian ini yaitu Alginat dan Zinc. Alginat memiliki porositas yang besar sehingga memiliki sifat gel yang kuat (Situngkir, 2008). 
Pada penelitian ini, material utama yang akan digunakan yaitu Hidroksiapatit (HA) yang dicampur dengan Alginat dan Zinc. Hidroksiapatit merupakan salah satu jenis garam Kalsium Fosfat (CaP) yang memiliki rumus kimia $\mathrm{Ca}_{10}\left(\mathrm{PO}_{4}\right)_{6}(\mathrm{OH})_{2}$. Namun, HA memiliki kelemahan, yaitu bersifat rapuh, sifat mekanik rendah, tidak osteoinduktif, dan ketidakstabilan struktur ketika tercampur dengan tubuh manusia (Shojai, Khorasani, Khoshdargi, \& Jamshidi, 2013). Untuk meningkatkan proses osteosis diperlukan material yang mempunyai sifat osteoinduksi pada HA sintetik. Material yang ditambahkan pada penelitian ini yaitu Alginat dan Zinc. Alginat memiliki porositas yang besar sehingga memiliki sifat gel yang kuat (Situngkir, 2008). Sedangkan Zinc memiliki fungsi sebagai proses perbaikan tulang, melakukan proses remodelling tulang, memberi sinyal pada sel osteoblast dan osteosit, serta mencegah pengeroposan tulang (Mulyaningsih, 2009).

Penelitian sebelumnya dilakukan oleh Ova (2013) dimana material yang digunakan yaitu HA dan Alginat. Alginat ditambahkan sebanyak 12\%. Uji tekan yang dihasilkan yaitu sebesar 3,061 MPa. Sedangkan pada penelitian Trisnawati (2014) dengan material HA dan Alginat dimana penambahan Alginat sebesar 14\% memberikan hasil uji tekan sebesar 5,68 $2,1 \mathrm{MPa}$. Hal ini dikatakan belum optimal dikarenakan tulang memiliki nilai tekan sebesar 7,5-41 MPa (Ylinen, 2006). Sedangkan, penelitian Setiadiputri (2018) dengan material HAAlginat-Zn dimana komposisi HA 88\%, Alginat 10\%, dan Zinc 2\% menghasilkan uji tekan sebesar $9,0107 \pm 0,1842 \mathrm{MPa}$. Sehingga, upaya yang dilakukan pada penelitian ini yaitu variasi komposisi pada material HA-Alginat-Zn. Perancangan biokomposit dilakukan dengan menggunakan metode Taguchi. Material pembentuk tulang tersebut akan dilakukan pengujian kuat tekan dengan tujuan meningkatkan sifat mekanis material. Hasil yang diharapkan yaitu dapat menentukan komposisi biokomposit HA-Alginat-Zn yang paling optimal terhadap kuat tekan bone scaffold dengan menggunakan metode Taguchi.

\section{STUDI LITERATUR}

Metode Taguchi merupakan metode yang memiliki tujuan untuk memperbaiki kualitas produk dan proses bersamaan dengan penekanan biaya dan sumber daya seminimal mungkin. Metode ini diperkenalkan oleh Dr. Genichi Taguchi pada tahun 1940 dengan sasaran menjadikan produk tahan terhadap noise (gangguan) sehingga sering disebut dengan robust design (Soejanto, 2009). Robust design yaitu penyusunan suatu kombinasi faktorfaktor yang kokos terhadap gangguan yang sulit dikendalikan serta menyebabkan kecenderungan untuk berubah-ubah pada produk lebih tinggi. Metode ini dapat merekayasa produktivitas yang bertujuan agar produk dapat berkualitas tinggi serta biaya yang rendah. Metode perancangan ini dana memperbaiki mutu dengan menghilangkan akibat dari variasi tanpa menghilangkan penyebabnya. Hal ini dilakukan dengan optimasi produk dan perancangan proses yang membuat produk tahan terhadap penyebab variasi suatu proses (Soejanto, 2009).

Pengembangan kualitas yang paling baik menurut Taguchi adalah mendesain dan membuat produk. Pengembangan kualitas dimulai ketika awal mendesain produk hingga lanjut ke proses produksi. Menurut Taguchi, kualitas yang buruk tidak dapat dieleminasi melalui pengembangan proses inspeksi, screening, dan pertolongan. Kualitas tidak dapat diletakkan kembali ke dalam produk secara keseluruhan. Desain produk dibuat dengan tujuan agar produk tersebut kuat terhadap robust dari faktor lingkungan yang tidak terkontrol. Taguchi menekankan bahwa kualitas apa yang harus di desain dari suatu produk dalam proses manufaktur. Konsep Taguchi ini mengaitkan bahwa kualitas dapat berkaitan secara langsung dengan parameter dari nilai target yang telah ada, bukan pada penampilan spesifikasi yang ditetapkan. Konsep ini dikembangkan menjadi besaran signal to noise ratio $(\mathrm{S} / \mathrm{N})$. Konsep selanjutnya yaitu disebut sebagai konsep kerugian (loss function) pengukuran simpangan dari parameter desain dengan batas-batas biaya dari Product Life Cycle (PLC). Biaya-biaya yang muncul yaitu biaya pengembangan produk, biaya sisa bahan, dan biaya pemeriksaan.

Desain proses berdasarkan konsep Taguchi dapat dibedakan menjadi tiga jenis selama proses produksi, diantaranya desain sistem, desain parameter, dan desain toleransi. Tahap ini membutuhkan pengetahuan yang detail dalam merancang desain sistem. Desain toleransi memiliki keterkaitan terhadap proses perkembangan produk dengan tujuan menentukan nilai optimal dari produk atau proses. Tujuan dari desain toleransi yaitu agar agar mendapatkan toleransi yang paling nominal dengan desain yang telah ditentukan oleh desain parameter (Fitria, 2009). 


\section{METODOLOGI}

Penelitian dibagi menjadi tempat pencampuran material dan tempat pengujian material. Tempat penelitian dalam melakukan pencampuran material HA-Alginat-Zn dilakukan di Laboratorium Pengembangan Proses dan Produk Jurusan Teknik Kimia UPN "Veteran" Yogyakarta. Sedangkan proses freeze drying dan pengujian kuat tekan akan dilakukan di Pusat Penelitian Biomaterial Lembaga Ilmu Pengetahuan Indonesia (LIPI). Waktu penelitian berdasarkan lamanya sintesis hingga karakterisasi sampel. Penelitian mulai dilaksanakan pada tanggal 19 Oktober 2020.

Objek yang diteliti dalam penelitian ini yaitu HA-Alginat-Zn sebagai bahan material scaffold lalu dilakukan proses pengujian pada hasil sampel tersebut. Pencampuran dan pengeringan material ini bertujuan untuk menghasilkan sampel yang nantinya digunakan sebagai material pengganti tulang manusia. Setelah sampel didapatkan, langkah selanjutnya yaitu dilakukan proses pengujian material dengan menggunakan uji tekan. Data tersebut yang akan diolah dengan menggunakan metode Taguchi untuk mendapatkan kualitas material yang sesuai dengan biaya yang rendah.

Bahan-bahan yang digunakan dalam perancangan material HA-Alginat-Zn yaitu Hidroksiapatit, Sodium Alginat, Phospate Buffer Saline (PBS), Zinc Nitrat 99\%, dan larutan Aquades. Sedangkan alat yang digunakan pada penelitian yaitu magnetic stirrer, timbangan digital, alat-alat laboratorium, alat uji tekan, freezer, dan freeze drying. Urutan penelitian dengan menggunakan metode Taguchi dimudahkan dengan membuat diagram alir dalam bentuk flowchart secara sistematis. Urutan tahapan penelitian dapat dilihat pada Gambar 1.

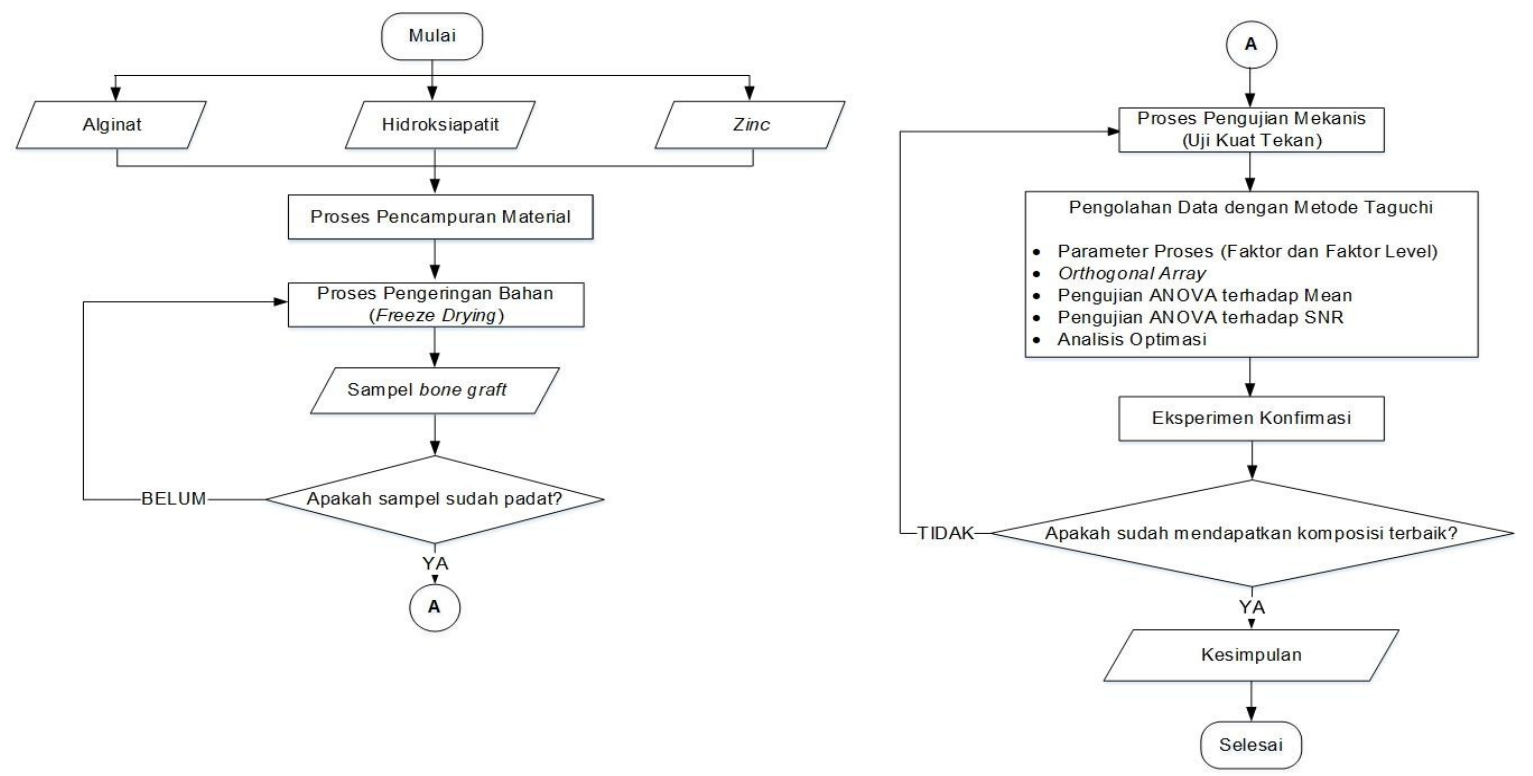

Gambar 1. Urutan tahapan penelitian

\section{HASIL DAN DISKUSI}

Hasil karakteristik kualitas yaitu larger-the-better dimana target kualitas yang digunakan nilai sebesarbesarnya (tak terhingga). Namun, tulang manusia memiliki target nilai uji tekan yaitu berada di antara 7,5-41 MPa. Sedangkan parameter yang digunakan pada penelitian ini yaitu faktor kontrol (terkendali), dimana faktor ini ditentukan oleh ahli teknik dan memiliki nilai satu atau lebih. Faktor kontrol dan level faktor dapat dilihat pada Tabel 1.

Tabel 1

Faktor kontrol

\begin{tabular}{lccc}
\hline \multicolumn{1}{c}{ Faktor } & Kode & Level 1 & Level 2 \\
\hline Komposisi HA (\%wt) & $\mathrm{A}$ & 86 & 88 \\
Komposisi Alginat (\%wt) & $\mathrm{B}$ & 6 & 8 \\
Rasio HA : Aquades & $\mathrm{C}$ & $1: 1$ & $1: 1,5$ \\
\hline
\end{tabular}


Berdasarkan perhitungan degree of freedom, didapatkan perhitungan total derajat kebebasan yaitu 3. Hal inimenunjukkan bahwa eksperimen harus dilakukan minimal sejumlah 8. Sehingga, didapatkan rancangan matriks orthogonal untuk desain eksperimen $\mathrm{L}_{4} 2^{3}$ yang disajikan pada Tabel 2.

Tabel 2

Matriks orthogonal $\mathrm{L}_{4} 2^{3}$

\begin{tabular}{cccc}
\hline Eks. & A & B & C \\
\hline 1 & 1 & 1 & 1 \\
2 & 1 & 2 & 2 \\
3 & 2 & 1 & 2 \\
4 & 2 & 2 & 1 \\
\hline
\end{tabular}

Pengujian kuat tekan material scaffold dengan diameter sampel sebesar $8 \mathrm{~mm}$ yang diuji menggunakan alatuji tekan ditunjukkan pada Tabel 3.

Tabel 3

Hasil uji kuat tekan

\begin{tabular}{|c|c|c|c|c|c|}
\hline Eks. & $\begin{array}{c}\text { Luas Penampang } \\
\left(\mathrm{mm}^{2}\right)\end{array}$ & $\begin{array}{c}\text { Beban Maksimal } \\
(\mathrm{N})\end{array}$ & $\begin{array}{l}\text { Kuat Tekan } \\
\text { (MPa) }\end{array}$ & Mean & $\begin{array}{c}\text { Signal Noise } \\
\text { Ratio }\end{array}$ \\
\hline \multirow{3}{*}{1} & \multirow{3}{*}{78,5} & 294 & 5,852 & \multirow{3}{*}{5,882} & \multirow{3}{*}{39,337} \\
\hline & & 299,2 & 5,955 & & \\
\hline & & 293,4 & 5,840 & & \\
\hline \multirow{3}{*}{2} & \multirow{3}{*}{78,5} & 341,7 & 6,801 & \multirow{3}{*}{6,852} & \multirow{3}{*}{38,297} \\
\hline & & 342 & 6,807 & & \\
\hline & & 349,1 & 6,949 & & \\
\hline \multirow{3}{*}{3} & \multirow{3}{*}{78,5} & 324 & 6,449 & \multirow{3}{*}{6,566} & \multirow{3}{*}{36,242} \\
\hline & & 333 & 6,628 & & \\
\hline & & 332,6 & 6,620 & & \\
\hline \multirow{3}{*}{4} & \multirow{3}{*}{78,5} & 406,2 & 8,085 & \multirow{3}{*}{8,074} & \multirow{3}{*}{49,017} \\
\hline & & 404 & 8,041 & & \\
\hline & & 406,7 & 8,095 & & \\
\hline
\end{tabular}

Data diolah dengan menggunakan dua acara, yaitu analysis of variance (ANOVA) terhadap nilai rata-rata dan ANOVA terhadap nilai SNR. ANOVA terhadap nilai rata-rata bertujuan untuk mencari faktor-faktor yang dapat mempengaruhi setting level. Perhitungan ANOVA dapat dilakukan dengan menggunakan aplikasi MINITAB 18 ataupun perhitungan manual. Pada jurnal ini akan dilakukan perhitungan ANOVA dengan cara manual menggunakan excel dan menggunakan aplikasi MINITAB 18. Tahap pertama yaitu menghitung nilai rata-rata untuk seluruh eksperimen. Hasil yang didapatkan yaitu 6,844 untuk rata-rata seluruh eksperimen. Selanjutnya yaitu dilakukan perhitungan nilai rata-rata untuk setiap level faktor. Hasil perhitungan disajikan pada tabel respon nilai rata-rata pada Tabel 4 sedangkan grafik respon dari nilai rata-rata dapat dilihat pada Gambar 2.

Tabel 4

Tabel respon nilai rata-rata

\begin{tabular}{cccc}
\hline \multirow{2}{*}{ Level } & \multicolumn{3}{c}{ Parameter Proses } \\
\cline { 2 - 4 } & $\mathrm{A}$ & $\mathrm{B}$ & $\mathrm{C}$ \\
\hline 1 & 6,367 & 6,224 & 6,978 \\
2 & 7,320 & 7,463 & 6,709 \\
\hline Selisih & 0,952 & 1,239 & 0,269 \\
\hline Ranking & 2 & 1 & 3 \\
\hline
\end{tabular}




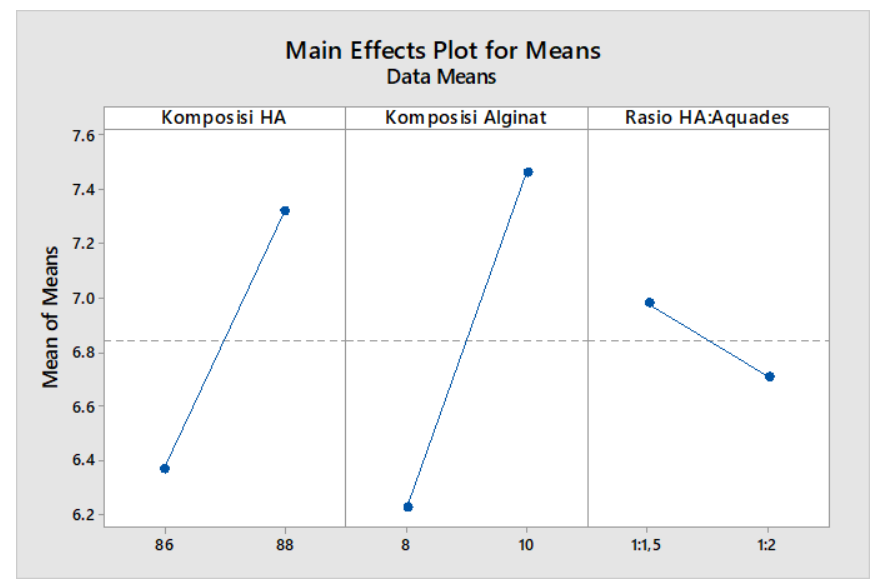

Gambar 2. Main effects plot for means

Selanjutnya, dilakukan perhitungan total sum of square sehingga didapatkan nilai sebesar 569,615. Tahap selanjutnya dilakukan perhitungan square due to mean dan dididapatkan nilai sebesar 562,027. Perhitungan berikutnya yaitu sum of square due to factors dan didapatkan nilai sebesar 2,721 untuk faktor A, 4,606 untuk faktor B, dan 0,217 untuk faktor C. Perhitungan berikutnya yaitu sum of square due to errors dimana didapatkan nilai error sebesar 0,044. Lalu perhitungan mean sum of square dan didapatkan nilai sebesar 2,721 untuk faktor A, 4,606 untuk faktor B, dan 0,217 untuk faktor C. Nilai probabilitas $\mathrm{P}$ pada perhitungan ini yaitu 0,05 dengan tingkat kepercayaan sebesar 95\%. Hasil perhitungan ANOVA terhadap nilai rata-rata lebih lengkap disajikan pada Tabel 5.

Tabel 5

Analysis of variance for mean

\begin{tabular}{|c|c|c|c|c|c|c|c|c|}
\hline $\begin{array}{l}\text { Sumber } \\
\text { Variasi }\end{array}$ & Pooled & $\mathrm{SS}$ & $\mathrm{DF}$ & MS & F ratio & $\mathrm{SS}^{\prime}$ & $\begin{array}{c}\% \frac{1}{\text { Kontribusi }} \\
\text { Ko }\end{array}$ & F tabel \\
\hline $\mathrm{A}$ & & 2,721 & 1 & 2,721 & 93,756 & 2,692 & $52,96 \%$ & 5,32 \\
\hline B & & 4,606 & 1 & 4,606 & 158,677 & 4,577 & $90,02 \%$ & 5,32 \\
\hline $\mathrm{C}$ & $\mathrm{Y}$ & 0,217 & - & - & - & - & - & 5,32 \\
\hline Error & $\mathrm{Y}$ & - & - & - & - & - & - & \\
\hline Pooled e & & 0,261 & 9 & 0,029 & 1 & $-2,185$ & $-42,98 \%$ & \\
\hline SSt & & 5,084 & 11 & 0,462 & - & 5,084 & $100.00 \%$ & \\
\hline Mean & & 562,027 & 1 & - & - & - & - & \\
\hline Total & & 569,615 & 12 & - & - & - & - & \\
\hline
\end{tabular}

Tahap pooling up merupakan rekomendasi penggunaan separuh jumlah derajat kebebasan pada orthogonal array yang digunakan. Pooling bertujuan untuk memperlakukan faktor tidak signifikan seolah-olah tidak ada dalam eksperimen dan jumlah kuadratnya merupakan bagian dari jumlah kuadrat karena error (SSe). Pool dapat dilakukan sebanyak mungkin pada faktor yang tidak signifikan serta menghitung jumlah kuadrat sesungguhnya terhadap faktor-faktor yang masih ada dan menyelesaikan nilai persen kontribusi. Dikarenakan semua faktor signifikan, maka faktor yang dilakukan pooling adalah faktor dengan F-ratio terkecil yaitu faktor C. Berdasarkan perhitungan ANOVA setelah pooling up dapat diketahui bahwa faktor A, faktor B, dan faktor C memiliki hasil yang signifikan dan mempengaruhi kuat tekan material scaffold. Dari tabel di atas, ditunjukkan bahwa persentase kontribusi dari error sebesar $-42,98 \%$ yang dapat diartikan bahwa semua faktor yang signifikan mempengaruhi nilai rata-rata sudah cukup dimasukkan ke dalam eksperimen. Syarat persen kontribusi error untuk metode Taguchi yaitu $\leq 50 \%$.

Selanjutnya yaitu dilakukan perhitungan ANOVA terhadap nilai SNR. Perhitungan ini digunakan dalam pencarian faktor yang memiliki nilai kontribusi terbesar pada pengurangan variansi suatu karakteristik kualitas. Perhitungan ANOVA terhadap nilai SNR diawali dengan mendapatkan nilai SNR untuk setiap eksperimen. Rumus yang digunakan untuk mengolah nilai SNR dengan karakteristik kualitas larger-the-better yaitu:

$$
\operatorname{SNR}=-10 \log 10\left(\frac{1}{N} \sum_{i=1}^{n}\left(\frac{1}{y_{i}}\right)^{2}\right)
$$

dimana $\mu$ menunjukkan rata-rata, sedangkan $\sigma$ menunjukkan nilai standar deviasi. 
Perhitungan ANOVA terhadap nilai SNR dilakukan dengan perhitungan manual menggunakan excel. Tahap pertama yaitu menghitung nilai SNR untuk seluruh eksperimen. Hasil yang didapatkan yaitu 40,723. Selanjutnya yaitu dilakukan perhitungan nilai SNR untuk setiap level faktor. Hasil perhitungan disajikan pada tabel respon nilai SNR pada Tabel 6 sedangkan grafik respon dapat dilihat pada Gambar 3.

Tabel 6

Tabel respon nilai SNR

\begin{tabular}{cccc}
\hline \multirow{2}{*}{ Level } & \multicolumn{3}{c}{ Parameter Proses } \\
\cline { 2 - 4 } & $\mathbf{A}$ & $\mathbf{B}$ & $\mathbf{C}$ \\
\hline $\mathbf{1}$ & 16,053 & 15,867 & 16,766 \\
$\mathbf{2}$ & 17,243 & 17,429 & 16,530 \\
\hline Selisih & 1,190 & 1,562 & 0,236 \\
\hline Ranking & 3 & 2 & 1 \\
\hline
\end{tabular}

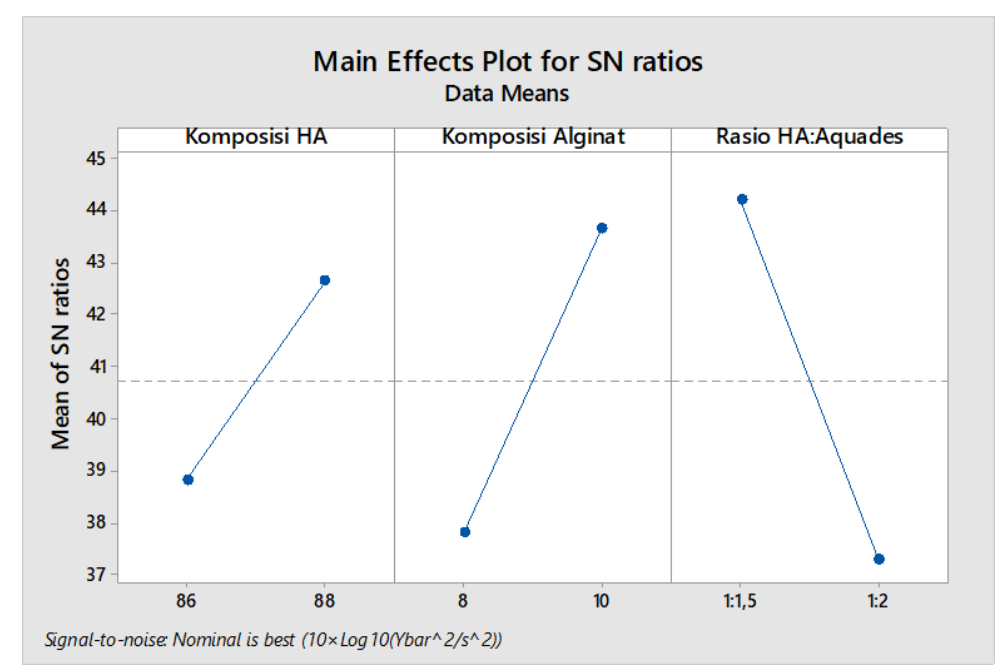

Gambar 3. Main effects plot for SNR

Selanjutnya, dilakukan perhitungan total sum of square sehingga didapatkan nilai sebesar 6730,200. Tahap selanjutnya dilakukan perhitungan square due to mean dan dididapatkan nilai sebesar 6633,521 . Hasil perhitungan ANOVA terhadap nilai SNR lebih lengkap disajikan pada Tabel 7.

Tabel 7

ANOVA nilai SNR

\begin{tabular}{ccccccccc}
\hline $\begin{array}{c}\text { Sumber } \\
\text { Variasi }\end{array}$ & Pooled & SS & DF & MS & F ratio & SS' & $\begin{array}{c}\% \\
\text { Kontribusi }\end{array}$ & F tabel \\
\hline A & & 1,415 & 1 & 1,415 & 25,373 & 1,360 & $34,77 \%$ & 161 \\
B & & 2,439 & 1 & 2,439 & 43,718 & 2,383 & $60,95 \%$ & 161 \\
C & Y & - & - & - & - & - & - & - \\
Error & Y & - & - & - & - & - & - & - \\
Pooled e & & 0,056 & 1 & 0,056 & 1 & 0,167 & $4,28 \%$ & \\
SSt & & 3,910 & 3 & 1,303 & & 3,910 & $100,00 \%$ & \\
Mean & & 1108,591 & 1 & & & & & \\
Total & & 1112,501 & 4 & & & & & \\
\hline
\end{tabular}

Dari tabel di atas dapat diketahui bahwa nilai Ftabel $(\mathrm{F}(0,05,1,1))=161$ lebih besar dari nilai Fratio setiap faktor. Hal ini menunjukkan bahwa faktor A maupun faktor B tidak mempengaruhi pengurangan variansi kuat tekan tulang. Sedangkan kontribusi faktor A dan B sebesar 34,77\% dan 60,95\%. Dan nilai error memiliki persentase kontribusi sebesar 4,28\% dimana syarat persen kontribusi error pada metode Taguchi yaitu $\leq 50 \%$ sehingga persentase kontribusi diterima. Tahap selanjutnya yaitu melakukan eksperimen konfirmasi yang bertujuan untuk memvalidasi kesimpulan yang telah diperoleh dari eksperimen sebelumnya. Eksperimen konfirmasi terdiri dari 5 sampel. Berikut merupakan hasil uji kuat tekan dari eksperimen konfirmasi. 
Tabel 8

Hasil kuat tekan eksperimen konfirmasi

\begin{tabular}{cccc}
\hline Eks. & $\begin{array}{c}\text { Luas Penampang } \\
\left(\mathrm{mm}^{2}\right)\end{array}$ & $\begin{array}{c}\text { Beban } \\
\text { Maksimal }(\mathrm{N})\end{array}$ & $\begin{array}{c}\text { Kuat Tekan } \\
(\mathrm{MPa})\end{array}$ \\
\hline 1 & 50,24 & 413,5 & 8,230 \\
2 & 50,24 & 412,1 & 8,203 \\
3 & 50,24 & 410,4 & 8,169 \\
4 & 50,24 & 410,8 & 8,177 \\
5 & 50,24 & 412,4 & 8,209 \\
\hline
\end{tabular}

Selanjutnya yaitu dilakukan perhitungan interval kepercayaan prediksi. Perhitungan ini akan dibagi menjadiinterval kepercayaan nilai rata-rata dan interval kepercayaan nilai SNR. Interval kepercayaan prediksi nantinyaakan dilakukan perbandingan dengan interval kepercayaan konfirmasi berdasarkan hasil eksperimen konfirmasi.Apabila nilai perkiraan sama atau mendekati nilai konfirmasi, maka dapat disimpulkan bahwa hasil eksperimenkonfirmasi berada di dalam interval optimal dan dapat diterima. Berdasarkan perhitungan perkiraan kondisi optimal, didapatkan nilai rata-rata prediksi sebesar 7,939 dan nilai SNR prediksi sebesar 47,111. Sedangkan, nilai rata-rata konfirmasi didapatkan sebesar 8,197 dan nilai SNR konfirmasi yaitu sebesar 50,327. Penjelasan lebih lengkap terkait interval kepercayaan nilai rata-rata dan nilai SNR dapat dilihat pada Tabel 9.

Tabel 9

Interval kepercayaan

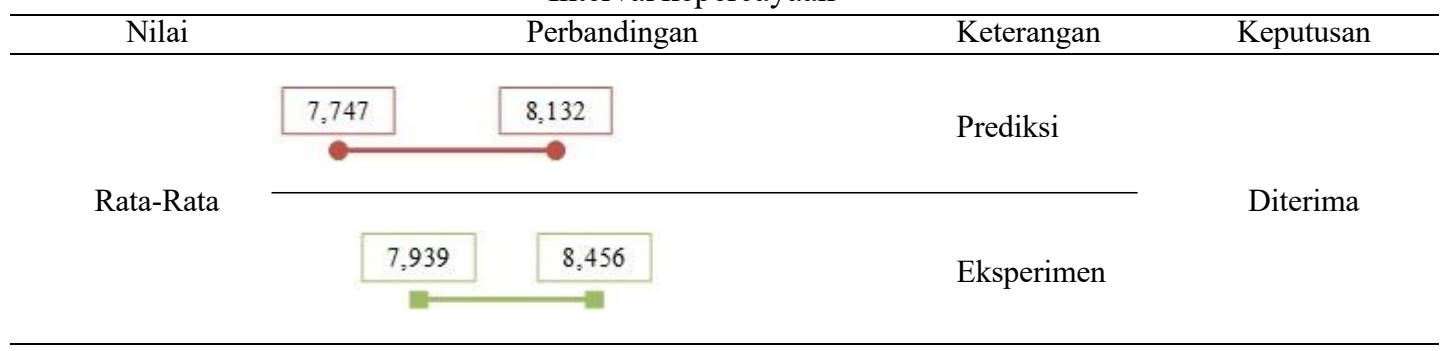

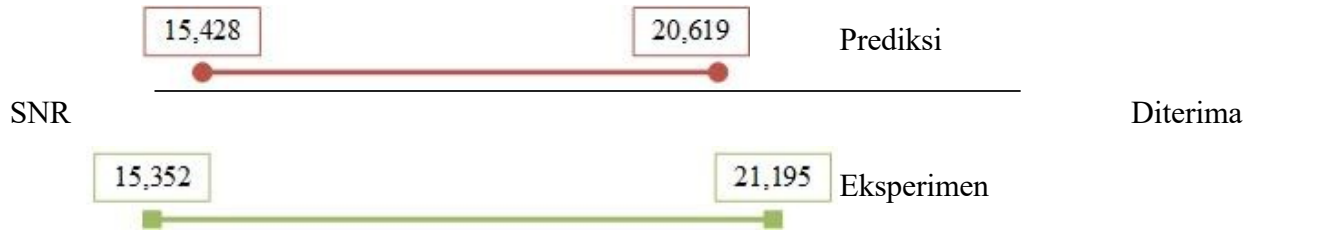

Berdasarkan perbandingan dengan interval kepercayaan optimal dan konfirmasi pada gambar di atas, dapat disimpulkan bahwa nilai konfirmasi sama atau mendekati nilai optimal. Sehingga, dapat dikatakan bahwa hasil eksperimen konfirmasi berada di dalam interval optimal dan dapat diterima.

\section{KESIMPULAN}

Berdasarkan penelitian yang telah dilakukan untuk menentukan komposisi biomaterial yang tepat terhadap kuat tekan material HA-Alginat-Zinc dengan menggunakan metode Taguchi, diperoleh kesimpulan, yaitu hasil perhitungan ANOVA terhadap nilai rata-rata menunjukkan bahwa faktor-faktor yang memiliki hasil signifikan dari eksperimen ini yaitu faktor A, faktor B, dan faktor C. Faktor C dilakukan pooling up dikarenakan memiliki nilai F-ratio terkecil. Sehingga, nilai kontribusi faktor A sebesar 52,96\% dan B dengan kontribusi sebesar $90,02 \%$.

Hasil perhitungan ANOVA terhadap nilai SNR menunjukkan bahwa faktor A, B, dan $\mathrm{C}$ tidak mempengaruhi pengurangan variansi dari karakteristik kualitas larger-the-better. Lalu, dilakukan pooling up terhadap faktor yang memiliki nilai Fratio terkecil yaitu faktor C. Sehingga, hasil kontribusi faktor A sebesar $34,77 \%$ dan faktor B sebesar 60,95\%.

Hasil perhitungan ANOVA terhadap nilai rata-rata maupun terhadap nilai SNR menunjukkan adanya setting level optimal dari faktor-faktor kontrol dimana faktor yang memiliki signifikansi lebih terhadap kuat tekan material scaffold yaitu komposisi HA 88wt\% (A2), komposisi Alginat 10wt\% (B2), komposisi Zinc 
Nitrat Tetrahidrat 2wt\%, dan rasio HA:Aquades 1:1,5 (C1). Sedangkan kuat tekan optimal yang didapatkan

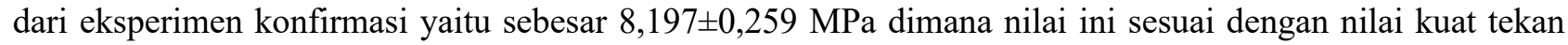
untuk tulang cancellous.

\section{DAFTAR PUSTAKA}

Badan Pusat Statistik. (2018). Tingkat Pengangguran Terbuka (TPT) sebesar 5,34 Persen. Diakses dari: https:/www.bps.go.id/pressrelease/2018/11/05/1485/agustus-2017-tingkatpengangguran-terbuka--tpt-sebesar-5-34- persen.html pada tanggal 28 November 2020, Jam 12.25 WIB.

Depkes RI. (2013). Riset Kesehatan Dasar. Jakarta: Badan Penelitian dan pengembangan Kesehatan Kementrian Kesehatan RI.

Ferdiansyah, Rushadi, D., Rantam, F. A., \& Aulani'am. (2011, September). Regenerasi pada Massive Bone Defect dengan Bovine Hydroxyapatite sebagai Scaffold Mesenchymal Stem Cell. Jurnal Bina Praja, 3(3), 179-195.

Fitria, Nana. (2009). Analisis Metode Desain Eksperimen Taguchi dalam Optimasi Karakteristik Mutu. Skripsi, Jurusan Matematika, Fakultas Sains dan Teknologi. Universitas Islam Negeri (UIN), Malang.

Malau, V., Wildan, M. W., Suyitno, \& Sadi. (2014). Optimization of Process Parameters of Stir Casting To Maximize The Hardness of Al-Sic Composites By Taguchi Method. International Journal of Applied Engineering Research, 9(24), 30121-30134.

Mulyaningsih, T. R. (2009). Kandungan Unsur Fe dan Zn dalam Bahan Pangan Produk Pertanian, Peternakan dan Perikanan dengan Metode k0-AANI. Indonesian Journal of Nuclear Science and Technology, 10(2), 71-80. doi:http://dx.doi.org/10.17146/jstni.2009.10.2.651

Ova, O. (2013). Optimasi Variasi Komposisi pada Proses Pembuatan Bone Graft Berbasis Hidroksiapatit dan Alginat. Skripsi. Departemen Fisika, Fakultas Sains dan Teknologi, Universitas Airlangga.

Prasetya, C., Rahman, A., \& Efranto, R. Y. (2013). Analisa Desain Eksperimen Pembuatan Batako Berbahan Alternatif Lumpur Lapindo dan Fly Ash dengan Metode Taguchi. Jurnal Rekayasa dan Manajemen Sistem Industri (JRMSI), 1(1), 57-65.

Setiadiputri, J. N. (2018). Sintesis dan Karakterisasi Biokomposit Hidroksiapatit-Alginat-Zinc sebagai Bone Graft Untuk Penanganan Bone Defect. Universitas Airlangga, Teknik Biomedis. Retrieved from http://repository.unair.ac.id/id/eprint/73827

Shojai, M. S., Khorasani, M. T., Khoshdargi, E. D., \& Jamshidi, A. (2013). Synthesis Methods for Nanosized Hydroxyapatite in Diverse Structures. Acta Biomaterialia, 9(8), 7591-7621.

doi:https://doi.org/10.1016/j.actbio.2013.04.012

Situngkir, J. (2008). Pembuatan dan Karakterisasi Fisiokimia Bahan Cetak Gigi Palsu Kalsium Alginat. Universitas Sumatera Utara, Kimia, Medan.

Soejanto, I. (2009). Desain Eksperimen dengan Metode Taguchi (Edisi Pertama, Cetakan Pertama ed.). Yogyakarta: Graha Ilmu.

Triono, P., \& Murinto. (2015, Juli). Aplikasi Pengolahan Citra untuk Mendeteksi Fraktur Tulang dengan Metode Deteksi Tepi Canny. 9(2), 1115-1123.

Trisnawati, M., Djony Izak, Siswanto. (2014). Sintesis dan Karakterisasi Bone Graft Hidroksiapatit-Alginat dengan Metode Ex-situ. Jurnal Fisika dan Terapannya, Vol. 2, No. 3, Universitas Airlangga, Surabaya.

Ylinen, P. (2006). Applications of Coralline Hydroxyapatite With Bioabsorbable Containment and Reinforcement As Bone Graft Substitute. Dissertation, University of Helsinki, Surgery, Helsinki. 